\title{
Article \\ Data-Independent Acquisition Enables Robust Quantification of 400 Proteins in Non-Depleted Canine Plasma
}

\author{
Halley Gora Ravuri ${ }^{1}$ (), Zainab Noor ${ }^{2}$, Paul C. Mills ${ }^{1}$, Nana Satake ${ }^{1, *}$ and Pawel Sadowski ${ }^{3, *(1)}$ \\ 1 School of Veterinary Science, The University of Queensland, Gatton, QLD 4343, Australia; \\ h.ravuri@uq.edu.au (H.G.R.); p.mills@uq.edu.au (P.C.M.) \\ $2 \operatorname{ProCan}^{\circledR}$, Children's Medical Research Institute, Faculty of Medicine and Health, The University of Sydney, \\ Westmead, NSW 2145, Australia; znoor@cmri.org.au \\ 3 Central Analytical Research Facility, Queensland University of Technology, Brisbane, QLD 4000, Australia \\ * Correspondence: nsatake@beckman.com (N.S.); pawel.sadowski@qut.edu.au (P.S.); Tel.: +61-731389541 (P.S.)
}

check for updates

Citation: Ravuri, H.G.; Noor, Z.; Mills, P.C.; Satake, N.; Sadowski, P. Data-Independent Acquisition Enables Robust Quantification of 400 Proteins in Non-Depleted Canine Plasma. Proteomes 2022, 10, 9. https://doi.org/10.3390/ proteomes10010009

Academic Editor: Bartosz Kempisty

Received: 30 December 2021

Accepted: 22 February 2022

Published: 28 February 2022

Publisher's Note: MDPI stays neutral with regard to jurisdictional claims in published maps and institutional affiliations.

Copyright: (C) 2022 by the authors. Licensee MDPI, Basel, Switzerland. This article is an open access article distributed under the terms and conditions of the Creative Commons Attribution (CC BY) license (https:// creativecommons.org/licenses/by/ $4.0 /)$.

\begin{abstract}
Mass spectrometry-based plasma proteomics offers a major advance for biomarker discovery in the veterinary field, which has traditionally been limited to quantification of a small number of proteins using biochemical assays. The development of foundational data and tools related to sequential window acquisition of all theoretical mass spectra (SWATH)-mass spectrometry has allowed for quantitative profiling of a significant number of plasma proteins in humans and several animal species. Enabling SWATH in dogs enhances human biomedical research as a model species, and significantly improves diagnostic and disease monitoring capability. In this study, a comprehensive peptide spectral library specific to canine plasma proteome was developed and evaluated using SWATH for protein quantification in non-depleted dog plasma. Specifically, plasma samples were subjected to various orthogonal fractionation and digestion techniques, and peptide fragmentation data corresponding to over 420 proteins was collected. Subsequently, a SWATH-based assay was introduced that leveraged the developed resource and that enabled reproducible quantification of 400 proteins in non-depleted plasma samples corresponding to various disease conditions. The ability to profile the abundance of such a significant number of plasma proteins using a single method in dogs has the potential to accelerate biomarker discovery studies in this species.
\end{abstract}

Keywords: dog; plasma proteomics; FASP; Data Independent Acquisition; SWATH

\section{Introduction}

Dogs are proving to be a useful model for many human diseases, such as osteosarcoma [1], prostate cancer [2], and lymphoma [3], and for developing therapeutic protocols during clinical trials [4]. Dogs are also useful translational models for epilepsy [5], autism [6], and the investigation of various zoonotic diseases [7]. Moreover, as companion animals, their health status and well-being are of utmost importance to their owners. Blood plasma is routinely collected from dogs and analyzed to assess health; however, surprisingly little assays are available for quantification of proteins in this species. Current veterinary diagnostic approaches are limited to targeting highly abundant proteins, such as albumin and globulins, using biochemical assays. Several major acute phase proteins (APPs) and a few cytokines can be measured using traditional protein quantitation methods, including enzyme-linked immunosorbent assays (ELISA), and radioimmune assays (RIA), but they were developed for other species and assume cross-reactivity with specific dog proteins [8]. Importantly, many oxidative markers and tissue leakage proteins are not routinely assessed due to the unavailability of relevant diagnostic kits.

Mass spectrometry offers a unique opportunity to quantify hundreds to thousands of proteins in a single assay; however, highly abundant proteins must be depleted to avoid interference with the detection of lower abundant proteins when protein quantitation 
is conducted using data-dependent acquisition (DDA)-based approaches [9]. The datadependent acquisition (DDA) approach used to be a standard data acquisition mode to identify proteins using LC-MS/MS in various biomarker discovery experiments. In this method, the most abundant ions (MS) entering the mass spectrometer are selected (in a small isolation window, with $<1 \mathrm{da}$ ) for MS/MS fragmentation. Each of these fragmented MS/MS scans is analyzed against proteome database search engines for the identification of proteins in samples [10]. Despite its successful application to biomarker discovery studies [11], the DDA technique is inherently biased with the selection of abundant precursor ions, which compromises the reproducible detection of smaller and less abundant peptides, as it also does with proteins [12,13].

The introduction of sequential window acquisition of all theoretical mass spectra (SWATH), a data-independent acquisition (DIA) approach available on selected mass spectrometry platforms [14], has overcome the limitation of abundance bias and has proven useful in quantifying proteins in non-depleted plasma samples from humans and laboratory animals $[15,16]$. In this acquisition mode, all peptides entering a mass spectrometer (irrespective of their abundance) will be fragmented (in consecutive isolation windows ranging between 10-50 da) within a given mass window (400-1200 m/z) [17], which enables reproducible quantitation of peptides from complex sample mixtures. However, SWATH data analysis relies on the availability of a highly curated DDA based reference spectral library, which should be well-annotated with a genome and contains information about peptide sequences, their chromatographic elution times, and characteristic product ions [18], and a significant community effort has been made to develop relevant resources for several species $[19,20]$. With the availability of spectral libraries in humans [21], SWATH is now extensively used to explore the pathophysiology of diseases in humans [22,23]. Recently, very few studies have reported the application of SWATH for the quantitation of proteins from plasma in dogs [24]; cattle [25] and sheep [26]. Most of these studies first developed an in-house DDA spectral library for enabling SWATH quantitation. Similarly, this study also utilized DDA mass spectrometry to generate a peptide spectral library in combination with several orthogonal fractionation and digestion approaches to identify the highest number of proteins over a previously published SWATH study [24]. In addition, we also proved that, when combined with a microflow liquid chromatography and a variable windows variant of SWATH, the library enabled development of a quantitative assay for robust monitoring of 400 proteins in clinically relevant and non-depleted plasma samples. We will share this development with the scientific community via PeptideAtlas portal [27] to underpin future studies in dogs.

\section{Materials and Methods}

\subsection{Sample Collection}

A total of 34 dog blood plasma samples (detailed information of each sample were provided as Supplementary Table S1) were obtained from archived samples stored in the Veterinary Diagnostic Laboratory in the School of Veterinary Science at The University of Queensland. The samples had been collected from clinically healthy subjects and animals with different clinical conditions (Table 1). This study has been approved by The University of Queensland Animal Ethics Committee (ANRFA/SVS/541/18).

\subsection{Sample Preparation}

All samples were acetone precipitated and subjected to various digestion and fractionation/enrichment techniques depending on the purpose of analysis, qualitative (Table 1) or quantitative (Table 2). 
Table 1. Samples used for generating peptide spectral library specific to dog blood plasma.

\begin{tabular}{|c|c|c|c|c|}
\hline No. & Condition & $\begin{array}{l}\text { No. of Animals } \\
\text { Used to Generate } \\
\text { a Pooled Sample }\end{array}$ & $\begin{array}{l}\text { Digestion } \\
\text { Technique }\end{array}$ & $\begin{array}{c}\text { Fractionation/Enrichmen } \\
\text { Technique }\end{array}$ \\
\hline 1 & Healthy & 8 & $\begin{array}{l}\text { In-solution } \\
\text { Filter-aided } \\
\text { In-gel }\end{array}$ & $\begin{array}{ll}\text { 1. } & \text { 1D_SDS PAGE } \\
\text { 2. } & \begin{array}{l}\text { ProteoMiner } \\
\text { enrichment }\end{array} \\
\text { 3. } & \begin{array}{l}\text { Acetonitrile } \\
\text { precipitation }\end{array}\end{array}$ \\
\hline 2 & $\begin{array}{l}\text { Unhealthy } \\
\text { (inflamma- } \\
\text { tory and } \\
\text { miscella- } \\
\text { neous } \\
\text { conditions) }\end{array}$ & 26 & Filter-aided & None \\
\hline
\end{tabular}

Table 2. Samples used for quantitative profiling of dog blood plasma proteins.

\begin{tabular}{ccccc}
\hline No. & Condition & $\begin{array}{c}\text { No. of Animals } \\
\text { Used to Generate } \\
\text { a Pooled Sample }\end{array}$ & $\begin{array}{c}\text { Digestion } \\
\text { Technique }\end{array}$ & $\begin{array}{c}\text { Fractionation/Enrichment } \\
\text { Technique }\end{array}$ \\
\hline 1 & Healthy & 8 & Filter-aided & None \\
\hline 2 & $\begin{array}{l}\text { Inflammatory } \\
\text { conditions }\end{array}$ & 8 & Filter-aided & None \\
\hline 3 & $\begin{array}{l}\text { Miscellaneous } \\
\text { conditions }\end{array}$ & 18 & Filter-aided & None \\
\hline
\end{tabular}

\subsubsection{Acetone Precipitation}

Samples were precipitated with cold acetone at $1: 4$ ratio and incubated at $-20{ }^{\circ} \mathrm{C}$ overnight. After incubation, precipitated samples were centrifuged at $250 \times g$ for $3 \mathrm{~min}$ and the pellet was resuspended in freshly prepared $8 \mathrm{M}$ urea in $25 \mathrm{mM}$ ammonium bicarbonate (AMBIC). The protein concentration was determined using the BCA protein assay kit (Pierce, Thermo Fisher Scientific, San Diego, CA, USA) as per the manufacturer's instructions.

\subsubsection{In-Solution Digestion}

The method followed was established by [28]. In brief, $20 \mu \mathrm{g}$ of plasma proteins were reduced using dithiothreitol (DDT) ( $5 \mathrm{mM}$ final concentration) and alkylated using iodoacetamide (IAM) (14 mM final concentration). The reaction was quenched by the addition of dithiothreitol (5 $\mathrm{mM}$ final concentration), and calcium chloride $\left(\mathrm{CaCl}_{2}\right)$ was added (10 $\mathrm{mM}$ final concentration). Protein digestion was performed adding sequencing grade modified trypsin (Promega, Madison, WI, USA) with 1:50 enzyme: protein ratio and agitated overnight at $37^{\circ} \mathrm{C}$. The next day, the resulting peptides were dried under vacuum and subjected to desalting.

\subsubsection{Filter-Aided Digestion (FASP)}

The method followed was established by [29]. Briefly, $20 \mu \mathrm{g}$ protein was mixed with Sodium dodecyl-sulfate (SDS)-Tris lysis buffer (4\% SDS, $100 \mathrm{mM}$ DTT in $100 \mathrm{mM}$ Tris$\mathrm{HCl}$ buffer $\mathrm{pH}$ 7.6) and transferred on to a $30 \mathrm{kDa}$ Microcon YM-30 centrifugal filter unit (Millipore, Merck KGaA, Darmstadt, Germany). Next, samples were mixed with DTT-Urea buffer (8 M urea and $25 \mathrm{mM}$ DTT in $100 \mathrm{mM}$ Tris-HCL pH 8.5) and the mixture was agitated for $1 \mathrm{~h}$ at room temperature. All the samples were centrifuged at $14,000 \times g$ for $15 \mathrm{~min}$ and mixed with IAM-Urea buffer ( $8 \mathrm{M}$ urea and $50 \mathrm{mM}$ iodoacetamide in $100 \mathrm{mM}$ Tris-HCL $\mathrm{pH}$ 8.5). The samples were centrifuged again followed by two washes with $100 \mathrm{mM}$ AMBIC. 
Finally, trypsin was added at an enzyme to protein ratio of 1:50 and the samples were agitated overnight at $37^{\circ} \mathrm{C}$. The following day, the peptides were eluted using $100 \mathrm{mM}$ AMBIC into a clean centrifuge tube, dried under vacuum, and subjected to desalting.

\subsubsection{ProteoMiner Enrichment}

The ProteoMiner protein enrichment kit enables enrichment of medium- and lowabundance proteins that cannot be detected through traditional methods. For depleting purposes, plasma samples were processed according to the manufacturer's instructions. Before processing plasma samples, all the spin columns were centrifuged at $1000 \times g$ for $60 \mathrm{~s}$ to remove all the storage material. The column was washed by adding $600 \mu \mathrm{L}$ Wash buffer, vortexed for $5 \mathrm{~min}$, followed by centrifugation at $1000 \times g$ for $60 \mathrm{~s}$, and the buffer was discarded. This step was repeated twice, involving washing and discarding the buffer-before plasma samples were processed. A total of $1000 \mu \mathrm{L}$ of plasma sample (with protein concentration $>50 \mathrm{mg} / \mathrm{mL}$ ) was added to the column and incubated for $2 \mathrm{~h}$ at $30^{\circ} \mathrm{C}$. After incubation, the column was centrifuged at $1000 \times \mathrm{g}$ for $60 \mathrm{~s}$ to remove the excess sample. Ligand beads were washed with the wash buffer by rotating for $5 \mathrm{~min}$, followed by centrifugation at $1000 \times g$ for $60 \mathrm{~s}$. Ligand beads were washed repeatedly three times before the elution process. After a couple of washings with the wash buffer, the column was washed with $600 \mu \mathrm{L}$ of de-ionized water by rotating for $1 \mathrm{~min}$, followed by centrifugation at $1000 \times g$ for $60 \mathrm{~s}$. The flow-through was discarded and the elution of the proteins was conducted by adding $100 \mu \mathrm{L}$ of elution reagent to the column. The column was vortexed for $15 \mathrm{~min}$, followed by centrifugation at $1000 \times g$ for $60 \mathrm{~s}$. The flowthrough was collected into a labeled collection tube. The elution process was repeated six times, all the elutes were pooled and were fractionated by SDS-PAGE and digested using the in-gel digestion protocol.

\subsubsection{SDS-PAGE Fractionation and In-Gel Digestion}

SDS-PAGE fractionation of samples was conducted based on a previously published method [30]. Briefly, $50 \mu \mathrm{g}$ protein was mixed with a sample buffer containing freshly added DDT (20 mM final concentration) and incubated at $60^{\circ} \mathrm{C}$ for $3 \mathrm{~min}$ before loading onto the gel. After completing the electrophoresis, the gel was stained with an Aqua stain solution for $5 \mathrm{~h}$ and then destained overnight with water. The gel was then cut into $5 \mathrm{~mm}$ slices and processed through in-gel digestion. In-gel digestion was performed on individual protein bands using a previously published method [31]. Gel slices were incubated in 50\% $\mathrm{ACN} / 100 \mathrm{mM}$ AMBIC at $4{ }^{\circ} \mathrm{C}$ for $30 \mathrm{~min}$, followed by incubation with $100 \% \mathrm{ACN}$ at room temperature. The process was repeated until there was no visible staining. Subsequently, the slices were cut into smaller pieces which were subjected to simultaneous reduction and alkylation using $10 \mathrm{mM}$ Tris(2-carboxyethyl) phosphine hydrochloride (TCEP) and $40 \mathrm{mM}$ chloroacetamide (CAA) in $100 \mathrm{mM}$ AMBIC for $30 \mathrm{~min}$. The gel pieces were then allowed to dry completely under a vacuum. Trypsin at an enzyme: protein ratio of approximately 1:50 based on the band intensity was added and incubated for $30 \mathrm{~min}$ at $4{ }^{\circ} \mathrm{C}$. Then $100 \mathrm{mM}$ AMBIC was added, and the samples were incubated at $37^{\circ} \mathrm{C}$ overnight on an agitator. The next day, trypsin digestion was stopped by using $4 \%$ formic acid. Peptides were extracted from gel pieces by agitating with $50 \%$ and $100 \% \mathrm{ACN}$ and the samples were dried under vacuum and subjected to desalting.

\subsubsection{Acetonitrile Precipitation}

A modified method established by [32] was followed with some modifications. Aliquots of raw plasma samples were diluted at a 1:10 ratio with $100 \mathrm{mM}$ ammonium acetate and their $\mathrm{pH}$ was adjusted to $3.5 ; 5$; 8 ; or 9 using either $100 \%$ acetic acid or $100 \mathrm{mM}$ ammonium bicarbonate. The samples were then mixed at a 1:1 ratio with $100 \%$ acetonitrile and centrifuged at $16,000 \times g$ for $10 \mathrm{~min}$. Supernatant and pellet fractions from each aliquot were collected separately and dried under vacuum. The dried samples were resuspended in $8 \mathrm{M}$ urea in $25 \mathrm{mM}$ AMBIC. The protein concentration was determined using BCA 
protein assay as per the manufacturer's instruction, and the samples were fractionated by SDS PAGE and digested using the in-gel protocol.

\subsubsection{Desalting}

Trypsin digested proteins were resuspended in $2 \% \mathrm{ACN}$ in $0.1 \%$ TFA and subjected to solid-phase extraction using a SCX membrane disk inserted into a StageTip [33]. Specifically, SCX material was activated using $100 \% \mathrm{ACN}$ and conditioned with $5 \%$ ammonium hydroxide in $80 \%$ ACN. SCX membrane equilibration, sample loading, and two washes utilized $2 \%$ ACN in $0.1 \%$ TFA. Finally, the peptides were eluted using $5 \%$ ammonium hydroxide in $80 \%$ ACN. Samples were then dried under vacuum and peptides were resuspended using a solution containing 11 standard peptides (iRT Kit from Biognosys) made up in $2 \%$ ACN in $0.1 \% \mathrm{FA}$ and submitted for mass spectrometry analysis.

\subsection{Mass Spectrometry}

\subsubsection{Data-Dependent Acquisition (DDA)}

For spectral library construction, peptide samples were analyzed on a TripleTOF 5600+ quadrupole time-of-flight mass spectrometer (SCIEX) operated in data-dependent acquisition (DDA) mode. The instrument was equipped with a Nanospray III ion source and coupled to the Eksigent ekspert nanoLC 400 System (Eksigent Technologies, Dublin, CA, USA) [26]. Chromatographic separation of peptides was performed using $150 \mathrm{~mm} \times 75 \mu \mathrm{m}$ column maintained at $40^{\circ} \mathrm{C}$ and packed with reverse phase material (ChromXP C18 $3 \mu \mathrm{m} 120 \AA$ ) preceded by trapping using $10 \mathrm{~mm} \times 0.3 \mathrm{~mm}$ trap cartridge packed with similar material (ChromXP C18CL $5 \mu \mathrm{m} 120 \AA$ ). The mobile phase A was water $/ 0.1 \%$ FA, mobile phase $\mathrm{B}-\mathrm{ACN} / 0.1 \%$ FA, and mobile phase $\mathrm{C}$ (for trapping) - $2 \%$ ACN $/ 0.1 \%$ FA. Peptides were trapped for $5 \mathrm{~min}$ at $5 \mu \mathrm{L} / \mathrm{min}$ followed by an elution across a $90 \mathrm{~min}$ run time using mobile phases $\mathrm{A}$ and $\mathrm{B}$ at a conserved flowrate of $300 \mathrm{~nL} / \mathrm{min}$. On DDA mode, a mass spectrometer performed high-resolution TOF-MS scans over 350-1350 $\mathrm{m} / \mathrm{z}$ range, followed by up to 40 high sensitivity MS/MS scans of the most abundant peptide ions per cycle over the range of $100-2000 \mathrm{~m} / \mathrm{z}$. Peptides with intensity greater than $150 \mathrm{cps}$ and a charge state of $2-5$ were selected for the analysis. The dynamic exclusion duration was adjusted depending on the peak widths. Each TOF-MS scan was performed for $250 \mathrm{~ms}$ and the product ion (MS/MS) scan was acquired for $50 \mathrm{~ms}$, resulting in a total cycle time of $2.3 \mathrm{~s}$. The ions were further fragmented in the collision cell, with collision energy spread (CEs) set at 5 , and the fragmented peptide ion spectra were saved in wiff format (SCIEX).

\subsubsection{Spectral Library Construction}

The protein sequence database was assembled in FASTA format downloaded on 20 March 2020 from a repository consisting of 45,351 proteome sequences non-redundant and predicted protein sequences of Canis lupus familiaris sourced from UniProtKB/SwissProt (Universal Protein Resource Knowledgebase-http:/ / www.uniprot.org/, accessed on 20 March 2020). The MS/MS spectra were annotated with amino acid sequences imported from canine database using the Paragon Algorithm provided in ProteinPilot v5.0 software (SCIEX) with the following search parameters: Digestion-Trypsin; InstrumentTripleTOF5600; Special Factors-Urea denaturation; Search effort-Thorough ID; ID FocusAmino acid substitution. The output file in group format was next used to build a spectral library inside Skyline software (Version 21.1.0.278) in blib format according to the published protocol [34]. The false discovery rate at the peptide level was set to $1 \%$ during data import.

\subsubsection{Data-Independent Acquisition}

For quantitative analysis, peptide samples were analyzed as four technical replicates on a TripleTOF 6600 quadrupole time-of-flight mass spectrometer (SCIEX) operated in data-independent acquisition (DIA) mode. For quantitative comparative SWATH analysis, all undepleted plasma samples (healthy, inflammatory, and miscellaneous) were digested using FASP with five technical replicates per condition. All the digested samples were 
analyzed using a variant of Data Independent Acquisition (variable windows SWATH) on TripleTOF 6600 quadrupole time-of-flight mass spectrometer (SCIEX) equipped with a Duo Spray Ion Source configured for microflow HPLC applications and coupled to Eksigent ekspert nanoLC 400 System (Eksigent Technologies, Dublin, CA, USA) also configured for microflow applications. Reversed-phase chromatography used trapping for $3 \mathrm{~min}$ at a flow rate of $10 \mu \mathrm{L} / \mathrm{min}$ onto a Trajan Protecol trap $(120 \AA, 3 \mu \mathrm{m}, 10 \mathrm{~mm} \times 300 \mu \mathrm{m})$ followed by separation on an Eksigent ChromXP C18 $3 \mu \mathrm{m} 120 \AA$ (3C18-CL-120, $3 \mu \mathrm{m}$, $120 \AA, 0.3 \times 150 \mathrm{~mm}$ ) analytical column at a flow rate of $5 \mu \mathrm{L} / \mathrm{min}$ maintained at $40{ }^{\circ} \mathrm{C}$. Trapping of peptides was done using mobile phase A $(0.1 \%$ FA in water) only, whereas separation was performed on a combination of mobile phase A and B $(0.1 \%$ FA in $100 \%$ ACN). A 68 min linear gradient of 3-25\% mobile phase B followed by a 5 min linear gradient of $25-35 \%$ mobile phase B, was used for separation of peptides, followed by the elution of peptides. The column was flushed with $80 \%$ of Mobile phase B for 5 min after each elution, and re-equilibration was done by $97 \%$ Mobile phase A for 8 min before next samples. Inside a mass spectrometer, eluted peptides were subjected to cyclic SWATH based on an approach published by [17] with modifications according to the current experiment. Specifically, a high-resolution $(30,000)$ TOF MS scan was collected over a range of $350-1500 \mathrm{~m} / \mathrm{z}$ for $50 \mathrm{~ms}$ and high-sensitivity TOF MS/MS scans over a range of $100-1800 \mathrm{~m} / \mathrm{z}$ over 100 variable Q1 windows (50 ms per window), resulting in the total duty cycle of $3.1 \mathrm{~s}$. The collision energy for each window was set using the collision energy of a $2+$ ion.

\subsubsection{Quantitative Analysis}

Targeted data extraction of all results from plasma analysis was performed using Skyline software [34] using a designed merged dog library. Retention time calibration and the prediction were performed using spiked-in Biognosys 11 standard peptides and chromatograms were extracted within the $20 \mathrm{~min}$ of predicted retention time. For quantitative analysis and peptides with Cut off score- 0.99 , precursor charges $-2,3,4$; Ion charges $-1,2,3$; Ion types-y, b; structural modification-carbamidomethyl (c) with a minimum dot $p$ value of 0.5 was considered for analysis. Further curation was done on the skyline document by removing repeated peptides, empty proteins, and duplicated proteins from the list. To estimate the false discovery rate (FDR) associated with target peptides, the 'secondbest peak' scoring model was designed using the mProphet algorithm [35] in Skyline. A FDR of $1 \%$ was applied and peptides passing the q-value cut-off of 0.01 with three out of four replicates were selected for quantification. For comparative SWATH analysis, five replicates per condition were selected for quantitation. The resulted peaks were further evaluated using different quality check parameters, including dot product (dotp) values which represent a correlation between observed (library) and measured (DIA) spectra, and ' 1 ' means a perfect match, mass accuracy, and coefficient of variation among technical replicates. Subsequently, to extract the report containing the list of quantified proteins and peptides and data related to SWATH extractions, the Skyline export report module was used. The settings used for targeted data extraction are submitted as Supplement Table S2. A differential expression analysis between three different conditions, healthy, inflammatory, and miscellaneous, was performed using MSstats [36]. Proteins with absolute log2 fold change $(\log 2 \mathrm{FC})>0.5$ and adjusted $p$-value $<0.05$ were considered as significant. All the library visualization, comparison plots and volcano were generated using scripts written in $\mathrm{R}$ programming language (Version 3.4). Data was plotted using the ggplot2 R package.

\section{Results}

\subsection{Protein Identifications from Different Digestion Techniques}

Various digestion techniques were employed to build an initial dog plasma proteome repository. In the case of samples collected for healthy animals, in-solution digestion resulted in the identification of 147 protein groups; FASP digestion identified 177 protein groups and in-gel digestion identified 169 protein groups (Figure 1). 


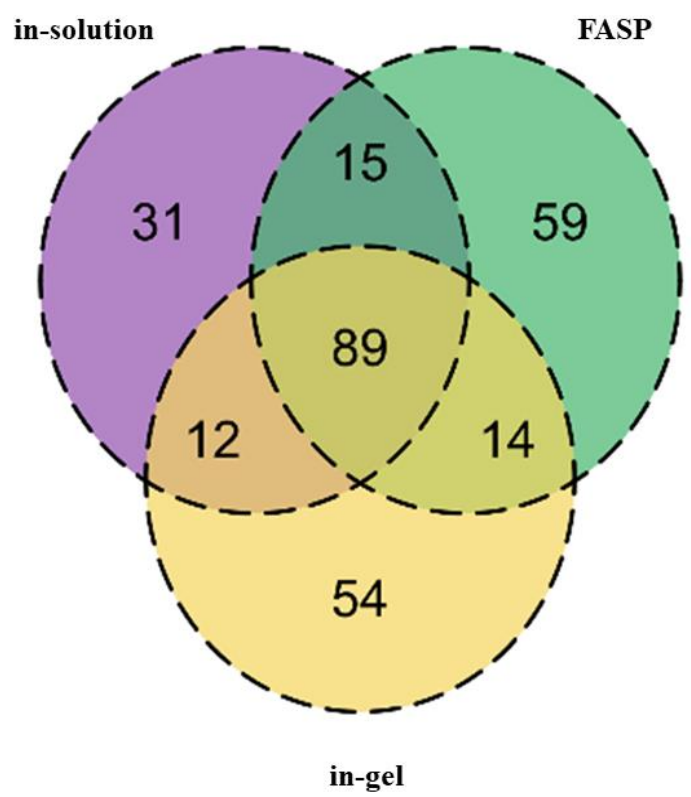

Figure 1. The Venn diagram represents the total number of identified proteins from plasma of healthy dogs after processing using different digestion techniques. Each digestion technique enabled the identification of different protein groups.

\subsection{Protein Identifications from Different Sample Types}

From the results shown above, FASP digestion was found to be superior compared to the other two digestion techniques to identify the maximum number of proteins from dog plasma. Therefore, FASP digestion was utilized for the digestion of samples collected from clinically unhealthy animals. This experiment resulted in the identification of 196 protein groups, 64 of which were uniquely identified in plasma corresponding to unhealthy conditions (Figure 2).

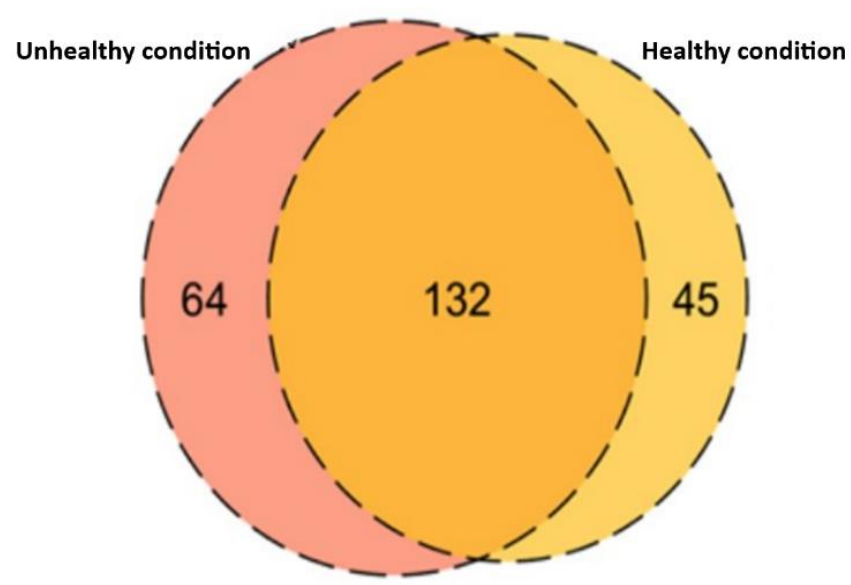

Figure 2. The Venn diagram represents the comparison of a total number of proteins identified in plasma collected from healthy and unhealthy animals. A total of 132 proteins were overlapped between the conditions and 64 proteins were unique to unhealthy and 45 proteins were unique to healthy conditions.

\subsection{Protein Identifications after ProteoMiner}

The pooled plasma samples collected from healthy dogs were processed using a ProteoMiner enrichment kit. SDS-PAGE was then used to visualise the difference between crude and treated samples (Figure $3 \mathrm{~A}$ ) and protein bands were digested for protein identification by mass spectrometry (Figure 3B). The absence of bands corresponding to albumin 
was evident for the ProteoMiner processed sample, which resulted in the identification of 293 protein groups. Only 169 proteins were detected in the case of crude plasma (Figure 3B).

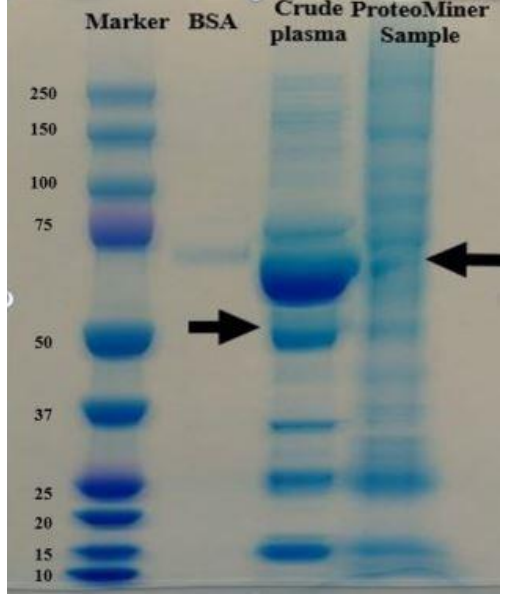

(A)

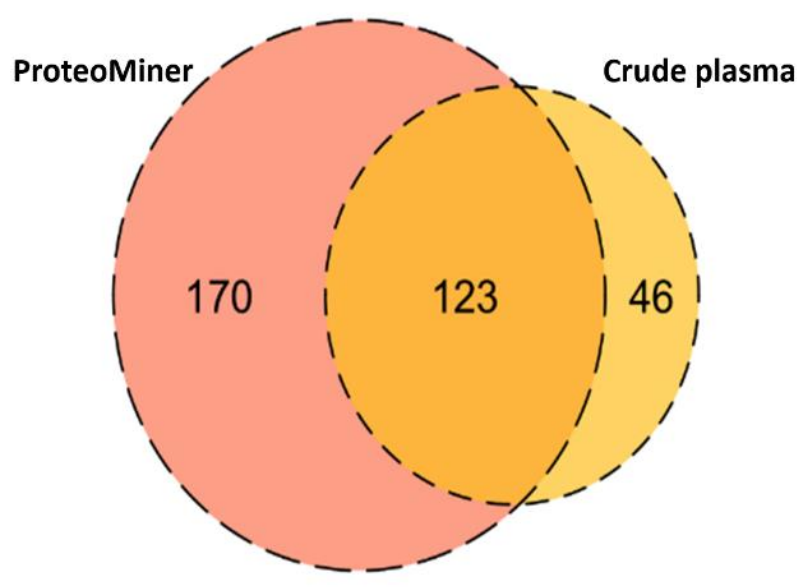

(B)

Figure 3. (A) SDS-PAGE of crude and ProteoMiner processed samples. Lane 1 = MW marker; Lane 2 = BSA; Lane 3 = crude dog plasma sample and Lane $4=$ ProteoMiner treated healthy dog plasma sample. The arrows indicate the main difference in the protein band patterns and corresponding to depletion of albumin in the case of the treated sample. (B) Venn diagram represents the comparison of the total number of proteins identified in crude dog plasma and ProteoMiner processed plasma collected from healthy animals. ProteoMiner treatment enabled identification of the highest number of unique proteins (170) over a crude untreated plasma sample (46 unique proteins).

\subsection{Protein Identifications after ACN Precipitation}

SDS-PAGE of precipitated samples (Figure 4A) demonstrated a clear difference between the protein band pattern in pellet fractions when compared with supernatant fractions. Most abundant proteins in the supernatant fraction were in the 10-75 kDa range. These were not visible and/or masked by the presence of high molecular weight proteins in the case of pellet fractions. Following in-gel digestion, a total of 211 protein groups were identified from all acetonitrile precipitated fractions (Figure 4B).

In the case of healthy dog plasma samples, ProteoMiner has resulted in the highest number of protein identifications, followed by ACN precipitation and in-gel digestion (Figure 5).

\subsection{Protein Quantitation Using Data-Independent Acquisition}

From all digestion and fractionation techniques employed, a library consisting of a total of 3119 peptides corresponding to 420 proteins (provided as the Supplementary Table S3) was generated and used for targeted extraction of SWATH data. At a $1 \%$ false discovery rate (FDR), all proteins were quantified from undepleted dog plasma samples using Skyline software that met quality and reproducibility criteria. Approximately 80\% of total quantified peptides had a coefficient of variation $(C V) \sim 25$. CV plot and other parameters characterising the quantitative assay based on the SWATH approach were included in Figure 6A-E and given as Supplementary Table S4.

To assess the applicability of a developed assay to clinical samples, undepleted dog plasma samples corresponding to three different conditions: healthy, inflammatory, and miscellaneous were digested in replicates $(n=5)$ and processed using FASP digestion prior to SWATH analysis. A total of 95 (Figure 7A) and 156 (Figure 7B) proteins were significantly altered in inflammatory and miscellaneous conditions respectively when compared to healthy condition. The list of proteins specific to each condition were given as Supplementary Tables S5 and S6. 


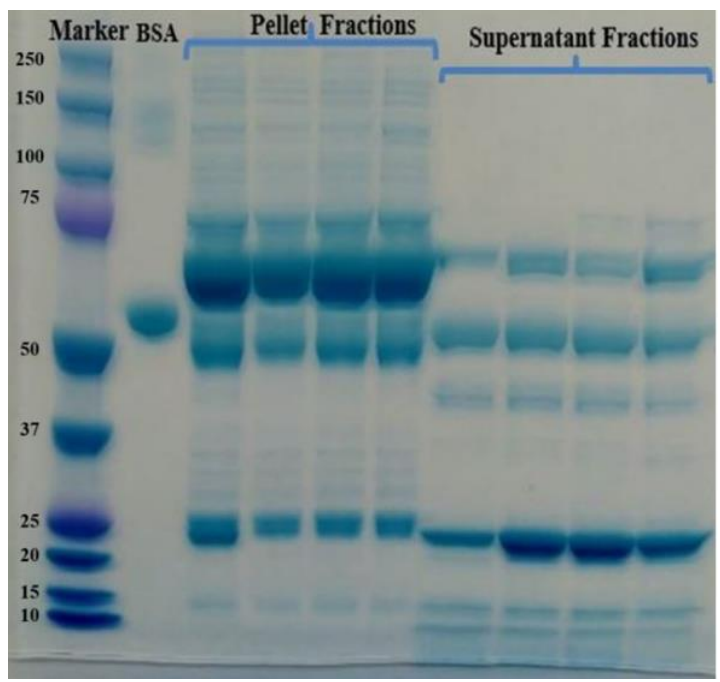

(A)

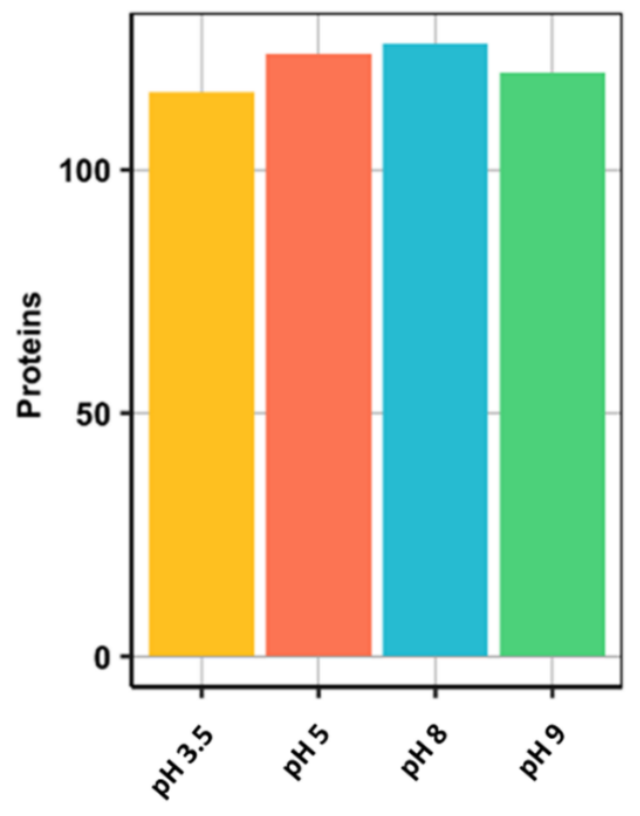

Pellet Fraction

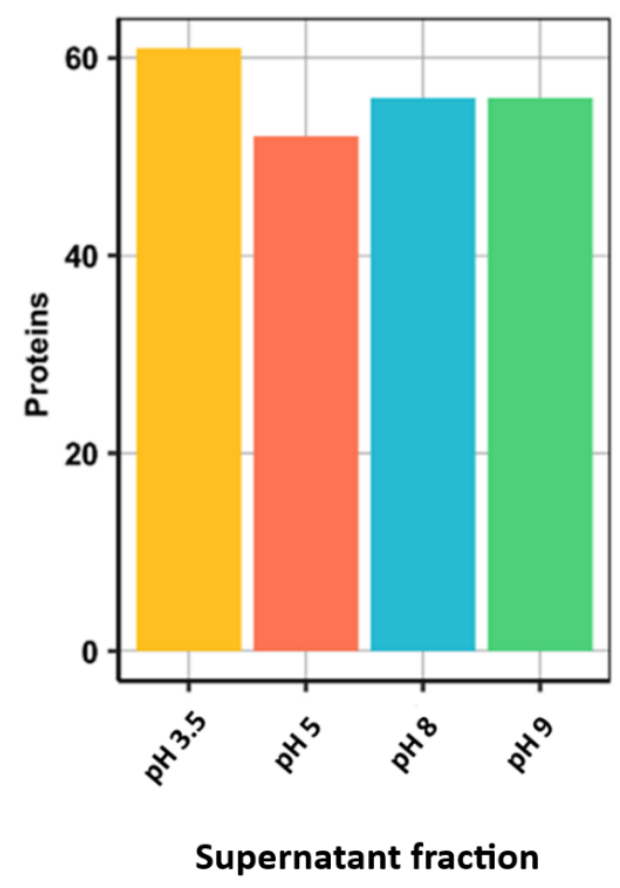

(B)

Figure 4. (A) SDS-PAGE of supernatant and pellet fractions of ACN precipitated healthy dog plasma samples. Lane 1 = MW marker; Lane 2 = BSA; Lanes 3-6 = pellet fractions collected at $\mathrm{pH} 3.5$, 5.0, 8.0 and 9.0, respectively; Lanes 7-10 = supernatant fractions collected at $\mathrm{pH} 3.5,5.0,8.0$ and 9.0, respectively. (B) Bar diagrams showing the total number of identified proteins from plasma of healthy dogs in different fractions resulting from $\mathrm{ACN}$ precipitation and collected at different $\mathrm{pH}$. Each bar represents an absolute number of protein groups identified in various fractions. At different $\mathrm{pH}$, protein precipitation resulted in the identification of a similar number of proteins. 


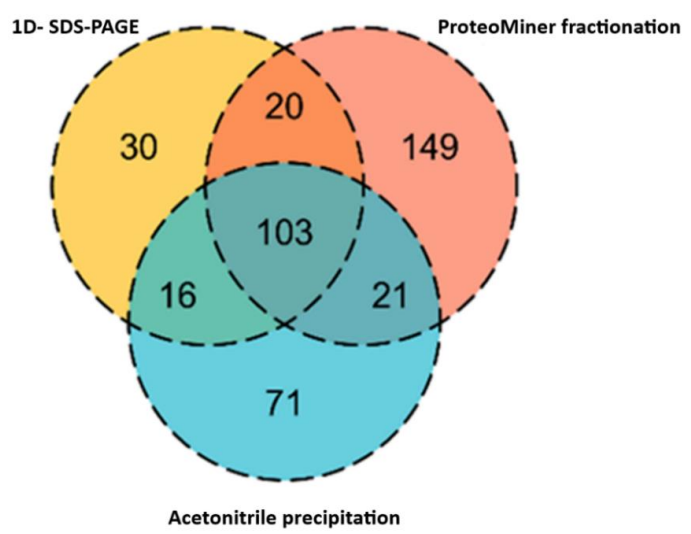

Figure 5. Venn diagram showing the contribution of different fractionation techniques to proteins represented in a spectral library. Most of the proteins were overlapped between the techniques, however, the highest number of unique proteins (149) were identified in ProteoMiner fraction, followed by ACN precipitation (71 unique proteins) and least identified in SDS-PAGE (30 unique proteins).
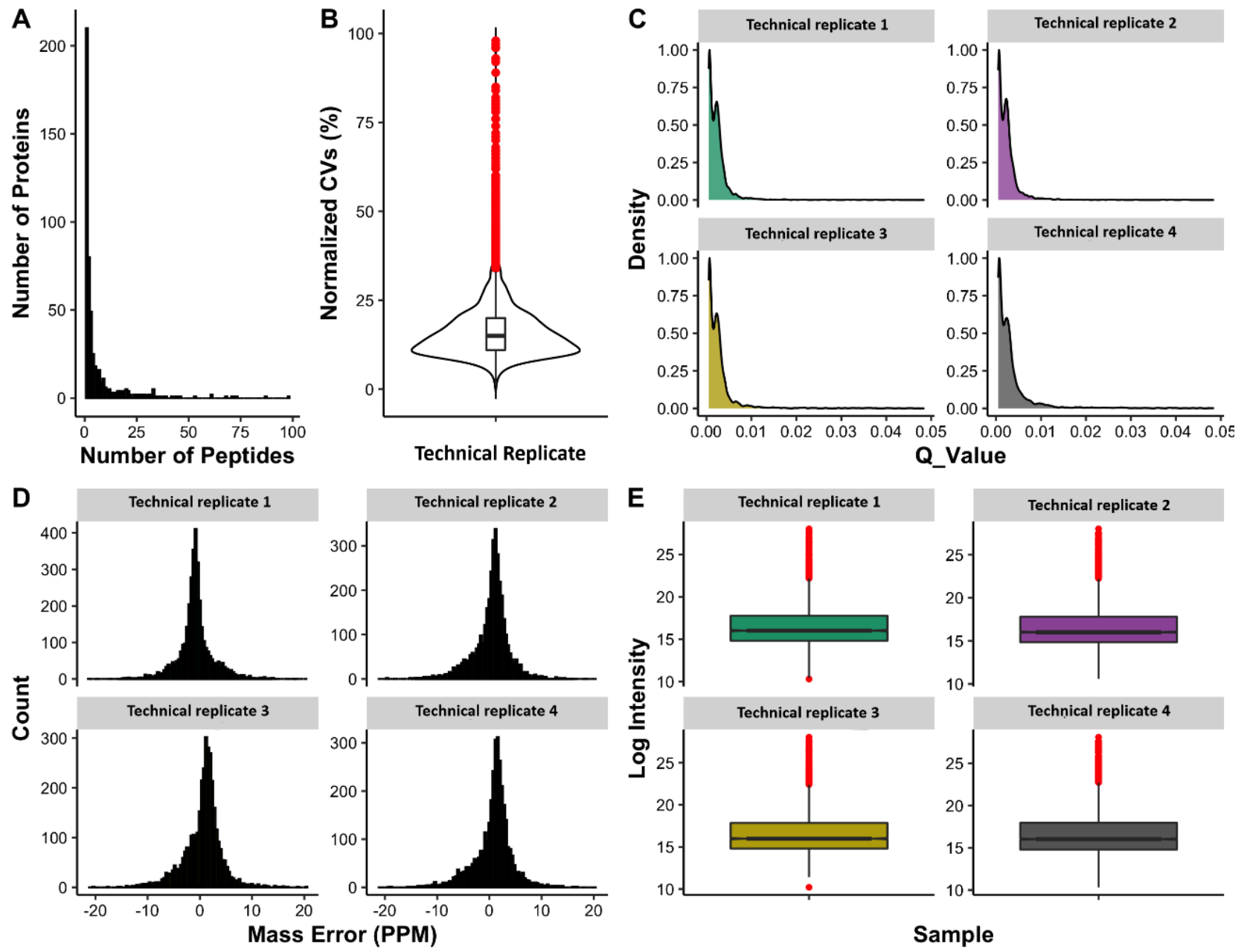

Figure 6. Characteristics of an assay to quantify 400 proteins in dog plasma. (A) Frequency plot of the number of peptides quantified per protein. (B) Violin plot of coefficient of variation (CV\%) among technical replicates - confirming the consistency of peptide quantification among technical replicates. (C) Distribution of q-values for extracted peaks. (D) Distribution of mass errors for extracted product ions. (E) Logged peptides intensity from all technical replicates showing the reproducibility of peptide quantitation. 
(A) Healthy Vs Inflammation

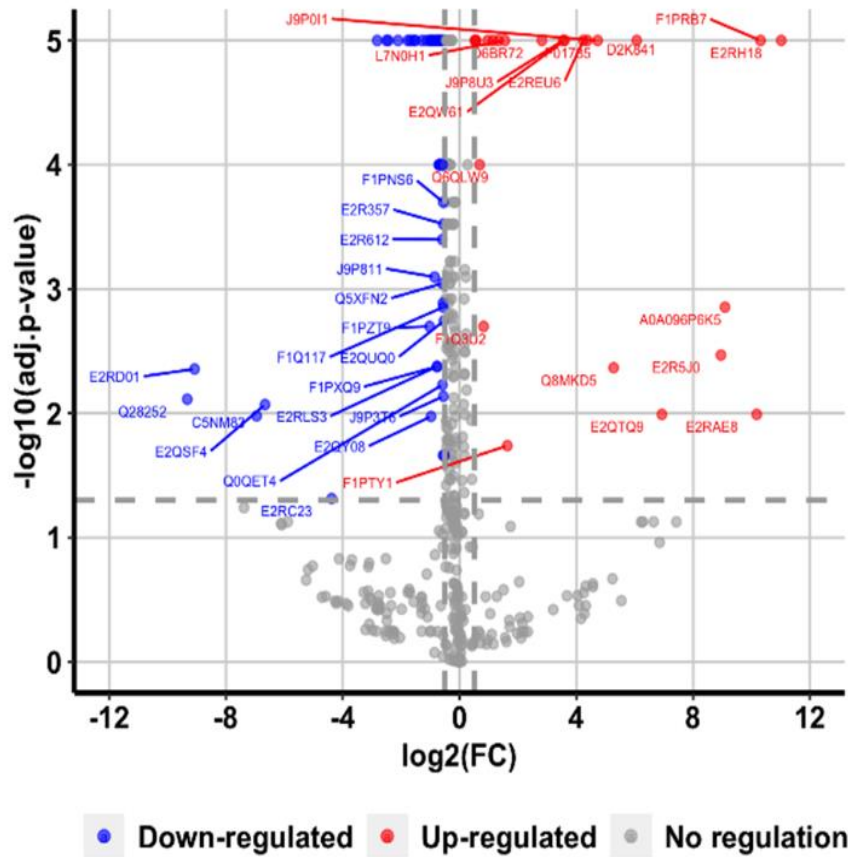

(B) Healthy Vs Miscellaneous

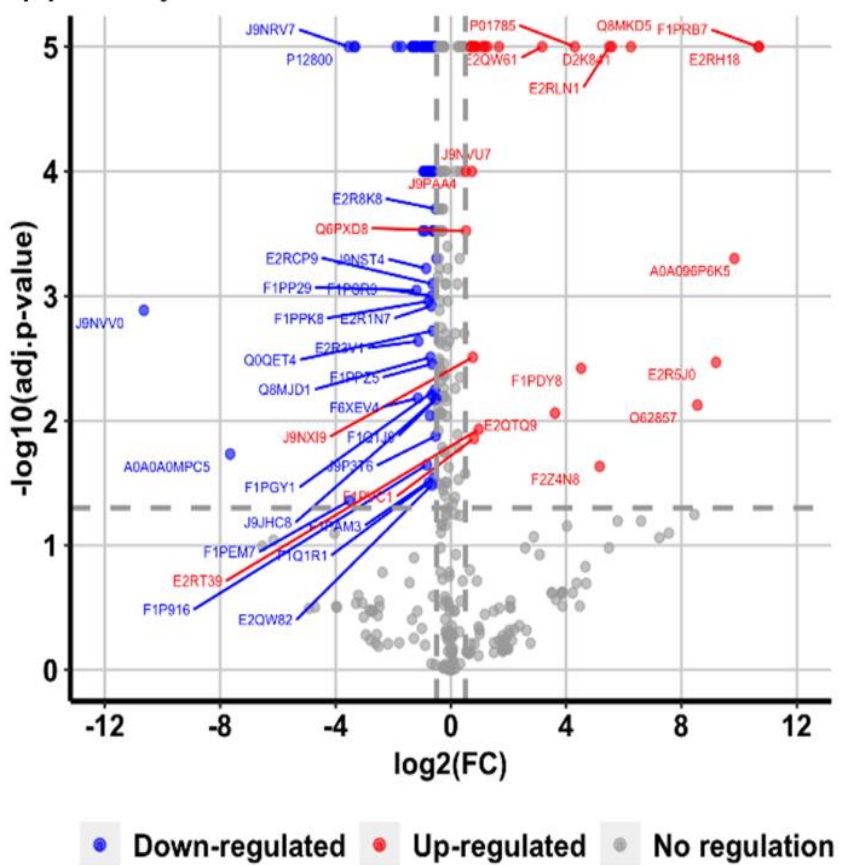

Figure 7. Volcano plot demonstrating changes in proteins corresponding to (A) inflammatory condition and (B) miscellaneous disease conditions, when compared to healthy samples. The X-axis displays the magnitude of fold changes and the Y-axis shows the statistical significance. The horizontal line indicates the adjusted $p$-value cut-off of $<0.05$, and vertical lines denote the absolute log 2 -fold change cut off of 0.5 . The blue dots represent downregulated and the red dots represent upregulated proteins in different clinical conditions.

\section{Discussion}

This study used different techniques to prepare samples for the canine spectral library, which was foundational for developing an assay to quantify more than 400 proteins in non-depleted plasma samples. For enabling SWATH quantitation, a reference DDA-based spectral library is required, which is genome annotated, consisting of a peptide fragmentation pattern and normalized retention time (RT) of all peptides for data extraction $[37,38]$. The generated reference library should contain all peptides of interest to enable detection and quantitation using SWATH [39]. Therefore, the first step in developing a spectral library is to choose a clinically relevant sample set and acquire MS/MS spectra of identified peptides [40]. The second step is to identify all possible peptides from samples, which is challenging in samples like serum/plasma due to the presence of a dynamic range of proteins [41]. Considering the stochastic nature of DDA, the generation of plasma spectral library requires depleting highly abundant proteins to reduce the complexity and increase the sensitivity of the assay [42]. In our study, we used various digestion and orthogonal fractionation techniques to increase plasma proteome coverage and the subsequent application of the developed assay to clinical samples enabled the detection of differentially abundant proteins discriminatory of the sample source which included known biomarkers of canine (Table 3) and human (Table 4) diseases. To our knowledge, this is the first time such a high number of proteins could be quantified from undepleted plasma in this species and shows the utility of the SWATH approach for clinical veterinary applications. 
Table 3. List of proteins present in the current generated spectral library and their involvement in different diseases of dogs.

\begin{tabular}{|c|c|c|c|}
\hline S1. No. & Disease Condition & Proteins Studied & Reference \\
\hline 1 & Canine Babesiosis & $\begin{array}{l}\text { Alpha } 1 \text { acid glycoprotein, } \\
\text { Apolipoprotein A-1, } \\
\text { Complement c3, Hemopexin, } \\
\text { Alpha 2-HS glycoprotein, } \\
\text { Haptoglobin, Clusterin }\end{array}$ & [43] \\
\hline 2 & Canine lymphoma & $\begin{array}{c}\text { Apolipoprotein A-I, } \\
\text { Apolipoprotein C-I, } \\
\text { Apolipoprotein C-II, } \\
\text { Apolipoprotein C-III, } \\
\text { Apolipoprotein E, } \\
\text { Beta-2-glycoprotein 1, Clusterin, } \\
\text { Coagulation factor IX, } \\
\text { Fibrinogen alpha chain, } \\
\text { Fibrinogen beta chain } \\
\text { (Fragment), } \\
\text { Fibrinogen gamma chain } \\
\text { Fibronectin, Haptoglobin, } \\
\text { Plasminogen } \\
\text { Serum amyloid A protein, } \\
\text { Transferrin receptor protein } 1\end{array}$ & {$[44]$} \\
\hline 4 & Canine Pyometra & $\begin{array}{l}\text { Alpha-1-acid glycoprotein 1, } \\
\text { Haptoglobin, } \\
\text { Alpha-2-macroglobulin, } \\
\text { Hemopexin, Transthyretin, } \\
\text { Transferrin receptor protein, } \\
\text { Retinol-binding protein, Gelsolin, } \\
\text { Alpha 2-HS glycoprotein }\end{array}$ & {$[45]$} \\
\hline 5 & $\begin{array}{c}\text { Canine Mammary } \\
\text { tumors }\end{array}$ & $\begin{array}{l}\text { Alpha-1-microglobulin/bikunin } \\
\text { precursor, Angiotensinogen, } \\
\text { Serum albumin, Gelsolin }\end{array}$ & [46] \\
\hline 6 & $\begin{array}{c}\text { Canine Chronic Valve } \\
\text { disease }\end{array}$ & $\begin{array}{l}\text { Apolipoprotein B, } \\
\text { Apolipoprotein M, } \\
\text { Apolipoprotein D }\end{array}$ & [47] \\
\hline 7 & $\begin{array}{l}\text { H3N2 canine } \\
\text { Influenza virus }\end{array}$ & $\begin{array}{l}\text { Haptoglobin, Apolipoprotein E, } \\
\text { Alpha } 1 \text { acid glycoprotein, } \\
\text { Beta-2-microglobulin }\end{array}$ & [48] \\
\hline 8 & $\begin{array}{c}\text { Duchenne muscular } \\
\text { dystrophy }\end{array}$ & $\begin{array}{l}\text { Alpha-1-B glycoprotein, Alpha } \\
\text { 2-HS glycoprotein, Fetuin B, } \\
\text { Hemopexin, Tropomyosin } 2\end{array}$ & [49] \\
\hline 10 & Canine Encephalitis & $\begin{array}{l}\text { Hemopexin, Gelsolin, } \\
\text { Transthyretin, } \\
\text { Beta-2-glycoprotein } 1 \\
\text { Apolipoprotein E }\end{array}$ & [50] \\
\hline 11 & Canine Leishmaniasis & $\begin{array}{l}\text { Haptoglobin, Hepatocyte growth } \\
\text { factor activator, Hyaluronan } \\
\text { binding protein } 2 \\
\text { Sulfhydryl oxidase, Complement } \\
\text { C8 alpha chain, Complement C9 }\end{array}$ & [24] \\
\hline
\end{tabular}


Table 4. List of proteins identified as biomarkers of different human diseases present in current dog spectral library.

\begin{tabular}{|c|c|c|c|}
\hline S1. No. & Protein Name & Human Disease Condition & Reference \\
\hline 1 & Gelsolin & Glioma & [51] \\
\hline 2 & Ceruloplasmin & $\begin{array}{l}\text { Identified as a protein biomarker } \\
\text { in prostate cancer }\end{array}$ & {$[52]$} \\
\hline 3 & Haptoglobin & $\begin{array}{l}\text { Identified as biomarker in lung } \\
\text { adeno carcinoma }\end{array}$ & {$[53]$} \\
\hline 4 & Alpha 1 antitrypsin & Studied in human breast cancer & [54] \\
\hline 5 & Vimentin & $\begin{array}{l}\text { Expressed in human and canine } \\
\text { osteosarcoma cells }\end{array}$ & [55] \\
\hline 6 & Tropomyosin 3 & $\begin{array}{l}\text { Upregulated in } \\
\text { metastatic carcinomas }\end{array}$ & \\
\hline $\begin{array}{l}7 \\
8\end{array}$ & $\begin{array}{l}\text { Myosin light chain } 2 \\
\text { Tropomyosin } 1\end{array}$ & $\begin{array}{l}\text { Downregulated in metastatic } \\
\text { mammary carcinoma, which is } \\
\text { also expressed in human } \\
\text { breast cancer }\end{array}$ & [56] \\
\hline 9 & $\begin{array}{l}\text { Triosephosphate } \\
\text { isomerase }\end{array}$ & $\begin{array}{l}\text { Analysed as autoantigens from } \\
\text { the canine mammary cell line }\end{array}$ & [57] \\
\hline $\begin{array}{l}10 \\
11\end{array}$ & $\begin{array}{c}\text { Transthyretin } \\
\text { Apolipoprotein A-I }\end{array}$ & $\begin{array}{l}\text { Identified as biomarkers for } \\
\text { detecting early stage of ovarian } \\
\text { cancer in human }\end{array}$ & [58] \\
\hline 12 & $\begin{array}{l}\text { Tissue inhibitor of } \\
\text { metalloproteinase } 1 \\
\quad \text { (Fragment) }\end{array}$ & Pancreatic cancer & [59] \\
\hline 13 & $\begin{array}{l}\text { Alpha 2-HS } \\
\text { glycoprotein } \\
\text { Transthyretin }\end{array}$ & Colorectal cancer & {$[60]$} \\
\hline
\end{tabular}

When generating this library, FASP digestion resulted in the identification of substantially more proteins compared to in-solution and in-gel digestion techniques (Figure 1); however, each approach contributed a unique set of proteins, thus expanding the library. The inclusion of samples corresponding to unhealthy animals and various fractionation techniques (SDS-PAGE, ProteoMiner, and ACN precipitation) further increased the number of proteins.

One concern when isolating proteins from plasma is that low abundant and low molecular weight proteins, such as tissue leakage proteins, may be obscured and the high abundant proteins need to be removed (depleted) to study low abundant proteins [61]. Several techniques, such as immuno depletion using ProteoPrep 20 and enrichment using Bio-Rad beads [62] and immune affinity depletion [63] have been used to deplete human plasma. However, each has drawbacks, including immuno-affinity kits being specific to human or laboratory rodent samples [64] and not suitable for veterinary species [65]. Fortunately, the ProteoMiner kit has been shown to be a useful depleting approach to cattle [66], pigs [65] and dogs [67]. In this study, the ProteoMiner kit has significantly (Figure 3A) depleted high abundant proteins, especially albumin in dog plasma, and had contributed a greater number of proteins (225) in this study. The ProteoMiner kit is comprised of different hexapeptide ligand beads, having an affinity to interact with all possible proteins in a sample [68]. High abundant proteins quickly oversaturate their ligands due to their abundance in plasma samples, and left-over unbound proteins will be removed in washes. On the other hand, ligand sites will be easily available for enriching low abundant proteins [69]. The results from previous studies and this current study proves 
that the ProteoMiner enrichment kit could be used for depleting high abundant proteins from plasma/serum in veterinary species.

Another significant advance in the current study was the fractionation of dog plasma using an organic solvent. Acetonitrile precipitation of plasma successfully depleted high abundant proteins in human serum [70], including when used under a range of $\mathrm{pH}$ conditions (5.0, 7.0, and 9.0) [32]. Acetonitrile precipitation of dog plasma at different $\mathrm{pH}(3.5,5$, 8 \& 9) does not completely remove the high abundant proteins like the ProteoMiner kit, but efficiently increased the identification of a greater number of proteins. This may be due to the effect of $\mathrm{pH}$ on protein solubility and molecular weight [70] and, similar to what has been reported for human serum samples [71], the use of the ProteoMiner enrichment kit followed by acetonitrile precipitation was superior for depleting high abundant proteins.

The quality and reproducibility of SWATH extractions were investigated using pooled healthy and unhealthy plasma samples as technical replicates $(n=4)$. Different parameters were applied to examine the reproducibility of the developed assay. As shown in Figure 6B, the majority of quantified peptides have coefficient of variation (CV) values less than $25 \%$ among technical replicates, such reproducibility in quantified values can also be visualized in Figure 6E, which shows the overall consistent intensity range within each sample or technical replicate. Moreover, in order to keep the high quality peptides, a q-value cut-off of 0.01 ( $1 \%$ FDR) was applied. Figure $6 \mathrm{C}$ shows the distribution of q-values for the quantified peptides, where virtually all of the peptides have a q-value $\leq 0.01$. Mass error shows the measure of difference between actual and theoretical mass of an ion and should be close to $0 \mathrm{ppm}$ for a high quality spectra. Figure $6 \mathrm{D}$ shows the distribution of mass error values with the mean value of $0 \mathrm{ppm}$ and an overall range of -10 to $10 \mathrm{ppm}$. These parameters add confidence to the protein and peptide quantifications among different samples and within replicates of the samples in the experiment. In this study, a spectral library was generated using information (in regards to instrumentation, and software analysis) from previously published DDA libraries in humans [14] and model animals [19,20,72]. Detailed information on generating spectral libraries, data acquisition, and DIA analysis has been discussed elsewhere $[73,74]$. In dogs, very few studies have reported spectral libraries using saliva [75] and tears [76]. None of these studies have evaluated the application of those libraries to deconvolute SWATH data. Recently, SWATH was used to explore serum proteomic alterations in different stages of Leishmania infected dogs [24]. In that study, a local spectral library was generated consisting of only 169 proteins (using SDSPAGE fractionation), which enabled the quantitation of only 44 significantly changed proteins specific to one disease condition in dogs. In contrast, our study had identified and quantitated the highest number of plasma proteins, which proves that the composition of the spectral library determines the efficiency of SWATH quantitation of proteins from undepleted plasma [77]. The advantage of our study was to include various clinical samples subjected a varied clinical conditions, which improved the quality of this plasma spectral library [78], and could be readily used to explore the pathophysiology of various clinical conditions. The main objective of this study was to develop a reproducible method that can quantify a maximal number of proteins in healthy and unhealthy subjects from undepleted plasma samples, which we believe was achieved in this study (Figures 6 and 7). The next step in our workflow is to apply this spectral library to investigate specific diseases in dogs. Recently, studies published from our research team have shown the importance of DDA libraries and their applicability to identify plasma biomarkers in cattle [25], and also discussed how combining spectral libraries could enable identification and quantitation of proteins [26] in similar species using SWATH.

It should also be noted that considering recent technical advances in the field of quantitative proteomics in human medicine, SWATH analysis could now be performed using in silico libraries using DeepDIA [79], and Prosit [80] instead of developing in-site DDA libraries. However, this could be possible only due to the availability of a fully annotated genome, which is currently lacking in all veterinary species [8]. This could be the next step to consider for biomarker discovery in veterinary proteomics. 


\section{Conclusions}

The current study has shown that a highly multiplexed and reproducible assay capable of quantifying $>400$ proteins in non-depleted plasma can be established using a purposebuilt spectral library. The proteins identified included acute phase proteins, oxidative stress markers and many other plasma proteins important to diagnosing canine diseases, such as osteoarthritis, pyometra and canine leishmaniosis. The assay and the published protocols can be utilized for biomarker discovery, diagnosis, and prognosis, while the methods and pipeline used may be useful for generating spectral libraries and establishing quantitative assays in other veterinary species.

Supplementary Materials: The following supporting information can be downloaded at: https: / / www.mdpi.com/article/10.3390/proteomes10010009/s1, Supplementary Table S1: Clinical plasma samples used for spectral library generation and SWATH quantitation; Supplementary Table S2: Skyline settings used for targeted data extraction; Supplementary Table S3: List of proteins identified in current spectral library. Supplementary Table S4: Peptide and protein reproducibility data of technical replicates; Supplementary Table S5: Proteins significantly altered in inflammatory samples, compared to healthy samples; Supplementary Table S6: Proteins significantly altered in inflammatory samples, compared to healthy samples.

Author Contributions: Conceptualization, H.G.R. and P.S.; Methodology, P.S. and N.S.; Formal analysis: H.G.R., Z.N. and P.S.; Investigation, H.G.R., N.S. and P.S.; Resources, P.C.M., N.S. and P.S.; Data Curation, H.G.R., Z.N. and P.S.; Writing-Original Draft Preparation, H.G.R., Z.N. and P.S.; Writing-Review \& Editing, P.S., Z.N. and P.C.M., Software, Z.N.; Visualization, H.G.R., P.S. and P.C.M.; Supervision, P.S., N.S. and P.C.M.; Project Administration, P.C.M.; Funding Acquisition, H.G.R., N.S. and P.C.M. All authors have read and agreed to the published version of the manuscript.

Funding: This research was funded by John and Mary Kibble trust with Grant number- 2017002693.

Institutional Review Board Statement: The study was conducted with approval obtained from the Institutional animal Ethics Committee of The University of Queensland (ANFRA: ANRFA/SVS/541/18, approved on 9 January 2019).

Informed Consent Statement: Not applicable.

Data Availability Statement: The data presented in this study are available on request from the corresponding author.

Acknowledgments: This work was enabled by use of the Central Analytical Research Facility (CARF) at the Queensland University of Technology (QUT).

Conflicts of Interest: The authors declare that they have no conflicts of interest.

\section{References}

1. Gregory, M.H.; Capito, N.; Kuroki, K.; Stoker, A.M.; Cook, J.L.; Sherman, S.L. A Review of Translational Animal Models for Knee Osteoarthritis. Arthritis 2012, 2012, 764621. [CrossRef] [PubMed]

2. Chevalier, S.; Moffett, S.; Turcotte, E.; Luz, M.; Chauvette, L.; Derbekyan, V.; Scarlata, E.; Zouanat, F.; Aprikian, A.G.; Anidjar, M. The Dog Prostate Cancer (DPC-1) Model: A Reliable Tool for Molecular Imaging of Prostate Tumors and Metastases. EJNMMI Res. 2015, 5, 77. [CrossRef] [PubMed]

3. Ratcliffe, L.; Mian, S.; Slater, K.; King, H.; Napolitano, M.; Aucoin, D.; Mobasheri, A. Proteomic Identification and Profiling of Canine Lymphoma Patients. Vet. Comp. Oncol. 2009, 7, 92-105. [CrossRef]

4. Gordon, I.; Paoloni, M.; Mazcko, C.; Khanna, C. The Comparative Oncology Trials Consortium: Using Spontaneously Occurring Cancers in Dogs to Inform the Cancer Drug Development Pathway. PLoS Med. 2009, 6, 2-6. [CrossRef]

5. Patterson, E.E. Canine Epilepsy: An Underutilized Model. ILAR J. 2014, 55, 182-186. [CrossRef]

6. Topál, J.; Román, V.; Turcsán, B. The Dog (Canis Familiaris) as a Translational Model of Autism: It Is High Time We Move from Promise to Reality. Wiley Interdiscip. Rev. Cogn. Sci. 2019, 10, e1495. [CrossRef] [PubMed]

7. Sanguansermsri, P.; Jenkinson, H.F.; Thanasak, J.; Chairatvit, K.; Roytrakul, S.; Kittisenachai, S.; Puengsurin, D.; Surarit, R. Comparative Proteomic Study of Dog and Human Saliva. PLoS ONE 2018, 13, e0208317. [CrossRef] [PubMed]

8. Ghodasara, P.; Sadowski, P.; Satake, N.; Kopp, S.; Mills, P.C. Clinical Veterinary Proteomics: Techniques and Approaches to Decipher the Animal Plasma Proteome. Vet. J. 2017, 230, 6-12. [CrossRef]

9. Beseme, O.; Fertin, M.; Drobecq, H.; Amouyel, P.; Pinet, F. Combinatorial Peptide Ligand Library Plasma Treatment: Advantages for Accessing Low-Abundance Proteins. Electrophoresis 2010, 31, 2697-2704. [CrossRef] 
10. Bateman, N.W.; Goulding, S.P.; Shulman, N.J.; Gadok, A.K.; Szumlinski, K.K.; MacCoss, M.J.; Wu, C.C. Maximizing Peptide Identification Events in Proteomic Workflows Using Data-Dependent Acquisition (DDA). Mol. Cell. Proteom. 2014, 13, 329-338. [CrossRef]

11. Hu, A.; Noble, W.S.; Wolf-Yadlin, A. Technical Advances in Proteomics: New Developments in Data-Independent Acquisition. F1000Research 2016, 5, 419. [CrossRef]

12. Michalski, A.; Cox, J.; Mann, M. More than 100,000 Detectable Peptide Species Elute in Single Shotgun Proteomics Runs but the Majority Is Inaccessible to Data-Dependent LC-MS/MS. J. Proteome Res. 2011, 10, 1785-1793. [CrossRef] [PubMed]

13. Bereman, M.S.; Maclean, B.; Tomazela, D.M.; Liebler, D.C.; Maccoss, M.J. The Development of Selected Reaction Monitoring Methods for Targeted Proteomics via Empirical Refinement. Proteomics 2012, 12, 1134-1141. [CrossRef] [PubMed]

14. Rosenberger, G.; Koh, C.C.; Guo, T.; Röst, H.L.; Kouvonen, P.; Collins, B.C.; Heusel, M.; Liu, Y.; Caron, E.; Vichalkovski, A.; et al. A Repository of Assays to Quantify 10,000 Human Proteins by SWATH-MS. Sci. Data 2014, 1, 140031. [CrossRef] [PubMed]

15. Venable, J.D.; Dong, M.Q.; Wohlschlegel, J.; Dillin, A.; Yates, J.R. Automated Approach for Quantitative Analysis of Complex Peptide Mixtures from Tandem Mass Spectra. Nat. Methods 2004, 1, 39-45. [CrossRef] [PubMed]

16. Collins, B.C.; Hunter, C.L.; Liu, Y.; Schilling, B.; Rosenberger, G.; Bader, S.L.; Chan, D.W.; Gibson, B.W.; Gingras, A.C.; Held, J.M.; et al. Multi-Laboratory Assessment of Reproducibility, Qualitative and Quantitative Performance of SWATH-Mass Spectrometry. Nat. Commun. 2017, 8, 291. [CrossRef]

17. Gillet, L.C.; Navarro, P.; Tate, S.; Röst, H.; Selevsek, N.; Reiter, L.; Bonner, R.; Aebersold, R. Targeted Data Extraction of the MS/MS Spectra Generated by Data-Independent Acquisition: A New Concept for Consistent and Accurate Proteome Analysis. Mol. Cell. Proteom. 2012, 11, 1-17. [CrossRef]

18. Zi, J.; Zhang, S.; Zhou, R.; Zhou, B.; Xu, S.; Hou, G.; Tan, F.; Wen, B.; Wang, Q.; Lin, L.; et al. Expansion of the Ion Library for Mining SWATH-MS Data through Fractionation Proteomics. Anal. Chem. 2014, 86, 7242-7246. [CrossRef]

19. Krasny, L.; Bland, P.; Burns, J.; Lima, N.C.; Harrison, P.T.; Pacini, L.; Elms, M.L.; Ning, J.; Martinez, V.G.; Yu, Y.-R.; et al. A Mouse SWATH-Mass Spectrometry Reference Spectral Library Enables Deconvolution of Species-Specific Proteomic Alterations in Human Tumour Xenografts. Dis. Model. Mech. 2020, 13, dmm044586. [CrossRef]

20. Palmowski, P.; Watson, R.; Europe-Finner, G.N.; Karolczak-Bayatti, M.; Porter, A.; Treumann, A.; Taggart, M.J. The Generation of a Comprehensive Spectral Library for the Analysis of the Guinea Pig Proteome by SWATH-MS. Proteomics 2019, 19, e1900156. [CrossRef]

21. Liu, Y.; Buil, A.; Collins, B.C.; Gillet, L.C.; Blum, L.C.; Cheng, L.; Vitek, O.; Mouritsen, J.; Lachance, G.; Spector, T.D.; et al Quantitative Variability of 342 Plasma Proteins in a Human Twin Population. Mol. Syst. Biol. 2015, 11, 786. [CrossRef] [PubMed]

22. Kim, S.H.; Ahn, H.S.; Park, J.S.; Yeom, J.; Yu, J.; Kim, K.; Oh, Y.M. A Proteomics-Based Analysis of Blood Biomarkers for the Diagnosis of COPD Acute Exacerbation. Int. J. Chronic Obstr. Pulm. Dis. 2021, 16, 1497-1508. [CrossRef] [PubMed]

23. Liyanage, C.; Malik, A.; Abeysinghe, P.; Clements, J.; Batra, J. Swath-Ms Based Proteomic Profiling of Prostate Cancer Cells Reveals Adaptive Molecular Mechanisms in Response to Anti-Androgen Therapy. Cancers 2021, 13, 715. [CrossRef] [PubMed]

24. Franco-Martínez, L.; Villar, M.; Tvarijonaviciute, A.; Escribano, D.; Bernal, L.J.; Cerón, J.J.; Thomas, M.D.C.; Mateos-Hernández, L.; Tecles, F.; de la Fuente, J.; et al. Serum Proteome of Dogs at Subclinical and Clinical Onset of Canine Leishmaniosis. Transbound. Emerg. Dis. 2020, 67, 318-327. [CrossRef]

25. Ghodasara, P.; Satake, N.; Sadowski, P.; Kopp, S.; Mills, P.C. Investigation of Cattle Plasma Proteome in Response to Pain and Inflammation Using next Generation Proteomics Technique, SWATH-MS. Mol. Omics 2022, 18, 133-142. [CrossRef]

26. Noor, Z.; Paramasivan, S.; Ghodasara, P.; Chemonges, S.; Gupta, R.; Kopp, S.; Mills, P.C.; Ranganathan, S.; Satake, N.; Sadowski, P. Leveraging Homologies for Cross-Species Plasma Proteomics in Ungulates Using Data-Independent Acquisition. J. Proteom. 2022, 250, 104384. [CrossRef]

27. Desiere, F.; Deutsch, E.W.; King, N.L.; Nesvizhskii, A.I.; Mallick, P.; Eng, J.; Chen, S.; Eddes, J.; Loevenich, S.N.; Aebersold, R. The PeptideAtlas Project. Nucleic Acids Res. 2006, 34, 655-658. [CrossRef]

28. Villen, J.; Gygi, S.P. The SCX/IMAC Enrichment Approach for Global Phosphorylation Analysis by Mass Spectrometry. Nat. Protoc. 2008, 3, 1630-1638. [CrossRef]

29. Wiśniewski, J.R.; Zougman, A.; Nagaraj, N.; Mann, M. Universal Sample Preparation Method for Proteome Analysis. Nat. Methods 2009, 6, 359-362. [CrossRef]

30. Schägger, H. Tricine-SDS-PAGE. Nat. Protoc. 2006, 1, 16-22. [CrossRef]

31. Shevchenko, A.; Tomas, H.; Havliš, J.; Olsen, J.V.; Mann, M. In-Gel Digestion for Mass Spectrometric Characterization of Proteins and Proteomes. Nat. Protoc. 2007, 1, 2856-2860. [CrossRef] [PubMed]

32. Mostovenko, E.; Scott, H.C.; Klychnikov, O.; Dalebout, H.; Deelder, A.M.; Palmblad, M. Protein Fractionation for Quantitative Plasma Proteomics by Semi-Selective Precipitation. J. Proteom. Bioinform. 2012, 5, 217-221. [CrossRef]

33. Kulak, N.A.; Pichler, G.; Paron, I.; Nagaraj, N.; Mann, M. Minimal, Encapsulated Proteomic-Sample Processing Applied to Copy-Number Estimation in Eukaryotic Cells. Nat. Methods 2014, 11, 319-324. [CrossRef] [PubMed]

34. MacLean, B.; Tomazela, D.M.; Shulman, N.; Chambers, M.; Finney, G.L.; Frewen, B.; Kern, R.; Tabb, D.L.; Liebler, D.C.; MacCoss, M.J. Skyline: An Open Source Document Editor for Creating and Analyzing Targeted Proteomics Experiments. Bioinformatics 2010, 26, 966-968. [CrossRef] [PubMed]

35. Reiter, L.; Rinner, O.; Picotti, P.; Hüttenhain, R.; Beck, M.; Brusniak, M.Y.; Hengartner, M.O.; Aebersold, R. MProphet: Automated Data Processing and Statistical Validation for Large-Scale SRM Experiments. Nat. Methods 2011, 8, 430-435. [CrossRef] 
36. Choi, M.; Chang, C.Y.; Clough, T.; Broudy, D.; Killeen, T.; MacLean, B.; Vitek, O. MSstats: An R Package for Statistical Analysis of Quantitative Mass Spectrometry-Based Proteomic Experiments. Bioinformatics 2014, 30, 2524-2526. [CrossRef]

37. Röst, H.L.; Rosenberger, G.; Navarro, P.; Gillet, L.; Miladinoviä, S.M.; Schubert, O.T.; Wolski, W.; Collins, B.C.; Malmström, J.; Malmström, L.; et al. OpenSWATH Enables Automated, Targeted Analysis of Data-Independent Acquisition MS Data. Nat. Biotechnol. 2014, 32, 219-223. [CrossRef]

38. Pino, L.K.; Just, S.C.; MacCoss, M.J.; Searle, B.C. Acquiring and Analyzing Data Independent Acquisition Proteomics Experiments without Spectrum Libraries. Mol. Cell. Proteom. 2020, 19, 1088-1103. [CrossRef]

39. Bruderer, R.; Bernhardt, O.M.; Gandhi, T.; Xuan, Y.; Sondermann, J.; Schmidt, M.; Gomez-Varela, D.; Reiter, L. Optimization of Experimental Parameters in Data-Independent Mass Spectrometry Significantly Increases Depth and Reproducibility of Results. Mol. Cell. Proteom. 2017, 16, 2296-2309. [CrossRef]

40. Defossez, E.; Bourquin, J.; von Reuss, S.; Rasmann, S.; Glauser, G. Eight Key Rules for Successful Data-Dependent Acquisition in Mass Spectrometry-Based Metabolomics. Mass Spectrom. Rev. 2021, 1-13. [CrossRef]

41. Geyer, P.E.; Kulak, N.A.; Pichler, G.; Holdt, L.M.; Teupser, D.; Mann, M. Plasma Proteome Profiling to Assess Human Health and Disease. Cell Syst. 2016, 2, 185-195. [CrossRef]

42. Bauer, M.; Ahrné, E.; Baron, A.P.; Glatter, T.; Fava, L.L.; Santamaria, A.; Nigg, E.A.; Schmidt, A. Evaluation of Data-Dependent and -Independent Mass Spectrometric Workflows for Sensitive Quantification of Proteins and Phosphorylation Sites. J. Proteome Res. 2014, 13, 5973-5988. [CrossRef] [PubMed]

43. Kuleš, J.; Mrljak, V.; Rafaj, R.B.; Selanec, J.; Burchmore, R.; Eckersall, P.D. Identification of Serum Biomarkers in Dogs Naturally Infected with Babesia Canis Canis Using a Proteomic Approach. BMC Vet. Res. 2014, 10, 111. [CrossRef] [PubMed]

44. Fonghem, P.; Pisitkun, T.; Rattanapinyopituk, K.; Rungsipipat, A. Pre-Investigation Proteomic Profiles of Canine Lymphoma. Thai J. Vet. Med. 2017, 47, 191-192.

45. Kuleš, J.; Horvatić, A.; Guillemin, N.; Ferreira, R.F.; Mischke, R.; Mrljak, V.; Chadwick, C.C.; Eckersall, P.D. The Plasma Proteome and the Acute Phase Protein Response in Canine Pyometra. J. Proteom. 2020, 223, 103817. [CrossRef]

46. Franco-Martínez, L.; Gelemanović, A.; Horvatić, A.; Contreras-Aguilar, M.D.; Dabrowski, R.; Mrljak, V.; Cerón, J.J.; Martínez-Subiela, S.; Tvarijonaviciute, A. Changes in Serum and Salivary Proteins in Canine Mammary Tumors. Animals 2020, 10, 741. [CrossRef]

47. Kuleš, J.; Bilić, P.; Horvatić, A.; Kovačević, A.; Guillemin, N.; Ljubić, B.B.; Galan, A.; Jović, I.; Torti, M.; Rubić, I.; et al. Serum Proteome Profiling in Canine Chronic Valve Disease Using a TMT-Based Quantitative Proteomics Approach. J. Proteom. 2020, 223, 103825. [CrossRef]

48. Su, S.; Tian, J.; Hong, M.; Zhou, P.; Lu, G.; Zhu, H.; Zhang, G.; Lai, A.; Li, S. Global and Quantitative Proteomic Analysis of Dogs Infected by Avian-like H3N2 Canine Influenza Virus. Front. Microbiol. 2015, 6, 228. [CrossRef]

49. Guevel, L.; Lavoie, J.R.; Perez-Iratxeta, C.; Rouger, K.; Dubreil, L.; Feron, M.; Talon, S.; Brand, M.; Megeney, L.A. Quantitative Proteomic Analysis of Dystrophic Dog Muscle. J. Proteome Res. 2011, 10, 2465-2478. [CrossRef]

50. Nakamura, K.; Miyasho, T.; Nomura, S.; Yokota, H.; Nakade, T. Proteome Analysis of Cerebrospinal Fluid in Healthy Beagles and Canine Encephalitis. J. Vet. Med. Sci. 2012, 74, 751-756. [CrossRef]

51. Miyauchi, E.; Furuta, T.; Ohtsuki, S.; Tachikawa, M.; Uchida, Y.; Sabit, H.; Obuchi, W.; Baba, T.; Watanabe, M.; Terasaki, T.; et al Identification of Blood Biomarkers in Glioblastoma by SWATH Mass Spectrometry and Quantitative Targeted Absolute Proteomics. PLoS ONE 2018, 13, e0193799. [CrossRef] [PubMed]

52. Liu, Y.; Chen, J.; Sethi, A.; Li, Q.K.; Chen, L.; Collins, B.; Gillet, L.C.J.; Wollscheid, B.; Zhang, H.; Aebersold, R. Glycoproteomic Analysis of Prostate Cancer Tissues by SWATH Mass Spectrometry Discovers N-Acylethanolamine Acid Amidase and Protein Tyrosine Kinase 7 as Signatures for Tumor Aggressiveness. Mol. Cell. Proteom. 2014, 13, 1753-1768. [CrossRef] [PubMed]

53. Ortea, I.; Rodríguez-Ariza, A.; Chicano-Gálvez, E.; Vacas, M.S.A.; Jurado Gámez, B. Discovery of Potential Protein Biomarkers of Lung Adenocarcinoma in Bronchoalveolar Lavage Fluid by SWATH MS Data-Independent Acquisition and Targeted Data Extraction. J. Proteom. 2016, 138, 106-114. [CrossRef]

54. Bouchal, P.; Schubert, O.T.; Faktor, J.; Capkova, L.; Imrichova, H.; Zoufalova, K.; Paralova, V.; Hrstka, R.; Liu, Y.; Ebhardt, H.A.; et al. Breast Cancer Classification Based on Proteotypes Obtained by SWATH Mass Spectrometry. Cell Rep. 2019, 28, 832-843.e7. [CrossRef] [PubMed]

55. Roy, J.; Wycislo, K.L.; Pondenis, H.; Fan, T.M.; Das, A. Comparative Proteomic Investigation of Metastatic and Non-Metastatic Osteosarcoma Cells of Human and Canine Origin. PLoS ONE 2017, 12, e0183930. [CrossRef] [PubMed]

56. Klopfleisch, R.; Klose, P.; Weise, C.; Bondzio, A.; Multhaup, G.; Einspanier, R.; Gruber, A.D. Proteome of Metastatic Canine Mammary Carcinomas: Similarities to and Differences from Human Breast Cancer. J. Proteome Res. 2010, 9, 6380-6391. [CrossRef] [PubMed]

57. Zamani-Ahmadmahmudi, M.; Nassiri, S.M.; Rahbarghazi, R. Serological Proteome Analysis of Dogs with Breast Cancer Unveils Common Serum Biomarkers with Human Counterparts. Electrophoresis 2014, 35, 901-910. [CrossRef] [PubMed]

58. Kozak, K.R.; Su, F.; Whitelegge, J.P.; Faull, K.; Reddy, S.; Farias-Eisner, R. Characterization of Serum Biomarkers for Detection of Early Stage Ovarian Cancer. Proteomics 2005, 5, 4589-4596. [CrossRef]

59. Faca, V.M.; Song, K.S.; Wang, H.; Zhang, Q.; Krasnoselsky, A.L.; Newcomb, L.F.; Plentz, R.R.; Gurumurthy, S.; Redston, M.S.; Pitteri, S.J.; et al. A Mouse to Human Search for Plasma Proteome Changes Associated with Pancreatic Tumor Development. PLoS Med. 2008, 5, e123. [CrossRef]

60. Choi, J.W.; Liu, H.; Shin, D.H.; Yu, G.I.; Hwang, J.S.; Kim, E.S.; Yun, J.W. Proteomic and Cytokine Plasma Biomarkers for Predicting Progression from Colorectal Adenoma to Carcinoma in Human Patients. Proteomics 2013, 13, 2361-2374. [CrossRef] 
61. Ly, L.; Wasinger, V.C. Protein and Peptide Fractionation, Enrichment and Depletion: Tools for the Complex Proteome. Proteomics 2011, 11, 513-534. [CrossRef]

62. Hakimi, A.; Auluck, J.; Jones, G.D.D.; Ng, L.L.; Jones, D.J.L. Assessment of Reproducibility in Depletion and Enrichment Workflows for Plasma Proteomics Using Label-Free Quantitative Data-Independent LC-MS. Proteomics 2014, 14, 4-13. [CrossRef]

63. Beer, L.A.; Ky, B.; Barnhart, K.T.; Speicher, D.W. In-Depth, Reproducible Analysis of Human Plasma Using IgY 14 and SuperMix Immunodepletion. Methods Mol. Biol. 2017, 1619, 81-101. [CrossRef]

64. Echan, L.A.; Tang, H.Y.; Ali-Khan, N.; Lee, K.B.; Speicher, D.W. Depletion of Multiple High-Abundance Proteins Improves Protein Profiling Capacities of Human Serum and Plasma. Proteomics 2005, 5, 3292-3303. [CrossRef]

65. Marco-Ramell, A.; Bassols, A. Enrichment of Low-Abundance Proteins from Bovine and Porcine Serum Samples for Proteomic Studies. Res. Vet. Sci. 2010, 89, 340-343. [CrossRef]

66. Min, L.; Cheng, J.; Zhao, S.; Tian, H.; Zhang, Y.; Li, S.; Yang, H.; Zheng, N.; Wang, J. Plasma-Based Proteomics Reveals Immune Response, Complement and Coagulation Cascades Pathway Shifts in Heat-Stressed Lactating Dairy Cows. J. Proteom. 2016, 146, 99-108. [CrossRef]

67. Tvarijonaviciute, A.; Ceron, J.J.; de Torre, C.; Ljubić, B.B.; Holden, S.L.; Queau, Y.; Morris, P.J.; Pastor, J.; German, A.J. Obese Dogs with and without Obesity-Related Metabolic Dysfunction-A Proteomic Approach. BMC Vet. Res. 2016, 12, 211. [CrossRef]

68. Lee, P.Y.; Osman, J.; Low, T.Y.; Jamal, R. Plasma/Serum Proteomics: Depletion Strategies for Reducing High-Abundance Proteins for Biomarker Discovery. Bioanalysis 2019, 11, 1799-1812. [CrossRef]

69. Bandow, J.E. Comparison of Protein Enrichment Strategies for Proteome Analysis of Plasma. Proteomics 2010, 10, 1416-1425. [CrossRef]

70. Kay, R.; Barton, C.; Ratcliffe, L.; Matharoo-Ball, B.; Brown, P.; Roberts, J.; Teale, P.; Creaser, C. Enrichment of Low Molecular Weight Serum Proteins Using Acetonitrile Precipitation for Mass Spectrometry Based Proteomic Analysis. Rapid Commun. Mass Spectrom. 2008, 22, 3255-3260. [CrossRef]

71. De Jesus, J.R.; Galazzi, R.M.; de Lima, T.B.; Banzato, C.E.M.; Silva, L.F.D.A.L.E.; Dantas, C.D.R.; Gozzo, F.C.; Arruda, M.A.Z. Simplifying the Human Serum Proteome for Discriminating Patients with Bipolar Disorder of Other Psychiatry Conditions. Clin. Biochem. 2017, 50, 1118-1125. [CrossRef]

72. Blattmann, P.; Stutz, V.; Lizzo, G.; Richard, J.; Gut, P.; Aebersold, R. Generation of a Zebrafish SWATH-MS Spectral Library to Quantify 10,000 Proteins. Sci. Data 2019, 6, 190011. [CrossRef]

73. Schubert, O.T.; Gillet, L.C.; Collins, B.C.; Navarro, P.; Rosenberger, G.; Wolski, W.E.; Lam, H.; Amodei, D.; Mallick, P.; Maclean, B.; et al . Building High-Quality Assay Libraries for Targeted Analysis of SWATH MS Data. Nat. Protoc. 2015, 10, 426-441. [CrossRef] [PubMed]

74. Egertson, J.D.; Maclean, B.; Johnson, R.; Xuan, Y.; Maccoss, M.J. Multiplexed Peptide Analysis Using Data-Independent Acquisition and Skyline. Nat. Protoc. 2015, 10, 887-903. [CrossRef]

75. Bringel, M.; Jorge, P.K.; Francisco, P.A.; Lowe, C.; Sabino-Silva, R.; Colombini-Ishikiriama, B.L.; Machado, M.A.D.A.M.; Siqueira, W.L. Salivary Proteomic Profile of Dogs with and without Dental Calculus. BMC Vet. Res. 2020, 16, 1-12. [CrossRef]

76. Winiarczyk, M.; Winiarczyk, D.; Banach, T.; Adaszek, L.; Madany, J.; Mackiewicz, J.; Pietras-Ozga, D.; Winiarczyk, S. Dog Tear Film Proteome In-Depth Analysis. PLoS ONE 2015, 10, e0144242. [CrossRef]

77. Krasny, L.; Bland, P.; Kogata, N.; Wai, P.; Howard, B.A.; Natrajan, R.C.; Huang, P.H. SWATH Mass Spectrometry as a Tool for Quantitative Profiling of the Matrisome. J. Proteom. 2018, 189, 11-22. [CrossRef]

78. Bjelosevic, S.; Pascovici, D.; Ping, H.; Karlaftis, V.; Zaw, T.; Song, X.; Molloy, M.P.; Monagle, P.; Ignjatovic, V. Quantitative AgeSpecific Variability of Plasma Proteins in Healthy Neonates, Children and Adults. Mol. Cell. Proteom. 2017, 16, 924-935. [CrossRef]

79. Yang, Y.; Liu, X.; Shen, C.; Lin, Y.; Yang, P.; Qiao, L. In Silico Spectral Libraries by Deep Learning Facilitate Data-Independent Acquisition Proteomics. Nat. Commun. 2020, 11, 146. [CrossRef]

80. Gessulat, S.; Schmidt, T.; Zolg, D.P.; Samaras, P.; Schnatbaum, K.; Zerweck, J.; Knaute, T.; Rechenberger, J.; Delanghe, B.; Huhmer, A.; et al. Prosit: Proteome-Wide Prediction of Peptide Tandem Mass Spectra by Deep Learning. Nat. Methods 2019, 16, 509-518. [CrossRef] 